\title{
Intermetalītisko - ķīmisko savienojumu veidošanās un to izraisītās metālu sakausējumu struktūru izmaiņas atkarībā no to k̦īmisko elementu sastāva
}

\author{
Ingrīda Vītinaa ${ }^{1}$, Aija Krūmiṇa ${ }^{2}$, Velta Belmane ${ }^{3},{ }^{1-3} R T U$ Neorganiskās ķı̄mijas institūts
}

\begin{abstract}
Kopsavilkums. Intermetalīdu un ķīmisko savienojumu veidošanās, to klātbūtne rūpnieciskos izstrādājumos, kā metālu lūšanas cēlonis dzelzs un vara-cinka sakausējumos, pētīta, nosakot ķīmisko elementu sastāvu, sakausējumu struktūru un veicot rentgenfāžu analīzi. Struktūru izmaiñas sakausējumu rekristalizācijas procesos ar intermetalīdu, karbīdu un grafîta graudu izdalīšanos atkarībā no to ķīmiskā elementu sastāva pētītas ar optiskās mikroskopijas metodēm.
\end{abstract}

Atslēgas vārdi: intermetalīdi, metālu struktūra, ḳ̄miskais un fāžu sastāvs.

\section{IEVADS}

Pēdējos 10 gados aktualizējušies pētījumi par metālu rekristalizācijas procesiem, trauslo intermetalītisko un k̦īmisko savienojumu veidošanos metālu sakausējumos, kas bieži ir izstrādājumu sabrukšanas cēlonis. Metālu sakausējumu kīmisko elementu sastāvs nosaka to struktūru un fāžu stabilitāti, pretkorozijas, termisko un līdz ar to mehānisko izturību.

Intermetalītisko - k̦īmisko savienojumu veidošanās metālos ir atkarīga no to kīmisko elementu sastāva un ekspluatācijas apstākliem, bet kā aktuālu problēmu to izvirza:

- metālu ekonomijas politika pasaulē, kuras mērḳis ir samazināt izstrādājumu metāla ietilpību;

- nepieciešamība samazināt krāsaino metālu - Ni, Cr, Mo patēriņu leǵētajos tēraudos, leǵējošo elementu daudzumu vara sakausējumos;

- nepieciešamība respektēt ekoloǵijas prasības un nepielietot $\mathrm{Cd}, \mathrm{Be}, \mathrm{Pb}$, kā arī samazināt $\mathrm{Ni}$ un $\mathrm{Cr}$ patērinu, - nepieciešamība metalurǵijā izmantot metālu sakausējumu otrreizējo pārstrādi.

Tādēl, lai nodrošinātu metālu izstrādājumiem ekspluatācijas tehniskās garantijas, ekspluatācijas drošumu, t.sk. mehānisko, termisko un pretkorozijas izturību, ir nepieciešami jauni pêtījumi metālu ķīmijā un fizikā.

Lai risinātu šīs problēmas, strauji attīstās jaunu dzelzs sakausējumu - leǵēto tēraudu ražošana, kuros kā leǵējoši elementi bez Mo var būt $\mathrm{Co} \leq 11$ mas.\%, W 4,5-5,5 mas.\%, V $0,05-0,25$ vai $5,8-7,8$ mas. $\%$, Nb $0,1-3,0$ mas. $\%$ [1, 2, 3, 4, $5,6]$.

Lai paaugstinātu mehānisko izturību, novērstu augsttemperatūras koroziju un metāla oksidēšanos, dzelzs sakausējumiem bez $\mathrm{Ti}$ vai $\mathrm{Nb}$ pievieno arī $\mathrm{Zr}$ [2, 7, 8]. Veiktie salīdzinošie pētījumi par tēraudu termisko stabilitāti parāda, ka Cr-Mo tēraudu rekristalizāciju ar neatgriezeniskām metāla struktūras izmaināam, tā saucamo Creep procesu, nosaka tieši $\mathrm{Cr}$ un Mo daudzums. Dzelzs sakausējums ar $\mathrm{Cr}$ daudzumu
2,25 mas.\% un Mo daudzumu 1,0 mas.\% temperatūru intervālā no $500-600^{\circ} \mathrm{C}$ ir ar daudz augstāku pretoksidēšanās izturību, salīdzinot ar tēraudu, kurā šo elementu daudzums ir mazāks - Cr 1,25 un Mo 0,5 mas.\% [9].

Ni-Cr-Co sakausējumos, karsējot 2000 stundas 704 un $760^{\circ} \mathrm{C}$, notiek metālu karbīdu $\mathrm{MC}, \mathrm{M}_{23} \mathrm{C}_{6}$ un $\mathrm{M}_{6} \mathrm{C}$ veidošanās [10].

Pētījumos [11] par plaisu veidošanos metinājumu šuvju tuvumā 1. tabulā uzrādītajiem pamatmetāla un metināšanai izmantotā tērauda ķīmisko elementu sastāviem ir noteikts, ka, īslaicīgi karsējot $1313 \mathrm{~K} 4$ stundas un papildus 2 stundas, ilgstoši karsējot 923K 3000, 4000 un 7000 stundas, un nemainīgā spiedienā, sīkās karbīdu dalinnas kḷūst rupjgraudainākas, palielinās to daudzums tēraudā metinājuma šuves tā saucamajā pārkaršanas zonā. Konstatēta karbīdu veidošanās uz graudu robežvirsmām, kas savukārt izraisa tukšumu un vakanču veidošanos graudos. Ilgstošajā karsēšanas procesā turpinās lielo karbīdu graudu augšana uz graudu robežvirsmām, bet vienlaicīgi sākas sīku karbīdu graudu palielināšanās graudu iekšienē bāzes metāla metinājuma šuvei pieguḷošajā pārkaršanas zonā. Noteikts, ka ilgstošajā rekristalizācijas procesā veidojas karbīdi $\mathrm{Cr}_{23} \mathrm{C}_{6}$, $\mathrm{Cr}_{7} \mathrm{C}_{3}$ un k̦īmiskā savienojuma $\mathrm{Fe}_{2} \mathrm{~W}$ fāze. Ar rastra elektronu mikroskopiju noteikta graudu agregācija uz graudu robežvirsmām. Bāzes metālā metinājuma šuvei pieguḷošajā pārkaršanas zonā jau metināšanas procesā noteikta karbīdu MX klātbūtne, kur $\mathrm{M}$ var būt vanādijs vai niobijs, bet $\mathrm{X}$ ogleklis vai slāpeklis. Palielinoties karsēšanas un mehāniskā slogojuma ilgumam, palielinās šādu struktūru veidošanās, kas ir metāla plaisāšanas cēlonis.

Līdzīgi rezultāti par karbīdu veidošanos iegūti pētot dzelzs sakausējumu - tēraudu rekristalizāciju atkarībā no W daudzuma tajā [12].

Karsējot tēraudu no 1000 līdz 15000 stundām temperatūras intervālā no 823-923K, izmantojot mikroskopijas metodi, novērota rupju graudu struktūru veidošanās tēraudā, kas atbilst $\mathrm{M}_{23} \mathrm{C}_{6}$ tipa karbīdiem. Silšanas laikam palielinoties, novērota karbīdu aglomerācijas paātrināšanās, ko, kā norāda autori, nosaka tēraudā esošo ķīmisko elementu atomu savstarpējā difūzija. Taču šādu karbīda joslu veidošanās ir bijusi ievērojami mazāka, ja dzelzs sastāvam, kas dots 2. tabulā, pievieno W. Pētījumos ir noteikts, ka, tēraudu leǵējot ar 24 mas.\% W, ievērojami samazinās karbīda gaudu veidošanās. Šādu sakausējumu ar W daudzumu līdz 4 mas.\%, kā metālu ar paaugstinātām pretoksidēšanās un mehāniskām îpašībām ir ieteikts izmantot boileru un turbīnu ražošanā. Šāda tipa tēraudu iesaka papildus legête ar $\mathrm{Mo}, \mathrm{V}, \mathrm{Nb}$ un $\mathrm{B}$, lai to stabilizētu ilgstošā termiskā un mehāniskā slogojumā. 
1. TABULA

PAMATMETĀLA UN METINĀMĀ METĀLA K̦ĪMISKO ELEMENTU SASTĀVS (MAS.\%)

\begin{tabular}{|c|c|c|c|c|c|c|c|}
\hline & $\mathbf{C}$ & $\mathbf{S i}$ & $\mathbf{M n}$ & $\mathbf{S}$ & $\mathbf{P}$ & $\mathbf{C r}$ & $\mathbf{N i}$ \\
\hline Pamatmetāls & 0,10 & 0,47 & 0,4 & 0,001 & 0,008 & 8,77 & 0,12 \\
\hline $\begin{array}{c}\text { Metināmais } \\
\text { metāls }\end{array}$ & 0,12 & 0,29 & 0,7 & 0,008 & 0,009 & 9,08 & 0,49 \\
\hline
\end{tabular}

\begin{tabular}{|c|c|c|c|c|c|c|c|c|}
\hline & Mo & W & V & Nb & B & Al & $\mathbf{N}$ & $\mathrm{Fe}$ \\
\hline Pamatmetāls & 0,38 & 1,48 & 0,16 & 0,054 & 0,0011 & 0,02 & 0,043 & \multirow{2}{*}{$\begin{array}{l}\text { Bāzes } \\
\text { metāls }\end{array}$} \\
\hline $\begin{array}{l}\text { Metināmais } \\
\text { metāls }\end{array}$ & 0,42 & 1,72 & 0,19 & 0,06 & 0,003 & 0,01 & 0,06 & \\
\hline
\end{tabular}

2. TABULA

TĒRAUDA K̦̄MISO ELEMENTU SASTĀVS (MAS.\% )

\begin{tabular}{|r|c|c|c|c|c|c|c|c|}
\hline $\mathbf{C}$ & $\mathbf{C r}$ & $\mathbf{W}$ & $\mathbf{M n}$ & $\mathbf{S i}$ & $\mathbf{P}$ & $\mathbf{S}$ & $\mathbf{O}$ & $\mathbf{N}$ \\
\hline 0,104 & 8,96 & - & 0,49 & 0,30 & $<0,002$ & 0,003 & 0,011 & 0,002 \\
\hline
\end{tabular}

3. TABULA

TĒRAUDU ĶĪMISKO ELEMENTU SASTĀVS

\begin{tabular}{|l|c|c|c|c|c|c|c|}
\hline & C & Si & Mn & P & S & Cr & Mo \\
\hline TP316H & 0,092 & 0,39 & 0,44 & 0,011 & 0,003 & 8,68 & 0,92 \\
\hline Thermanìts & 0,052 & 0,51 & 1,77 & 0,031 & 0,006 & 16,76 & 2,05 \\
\hline Nicro 82 & 0,011 & 0,07 & 3,21 & 0,004 & 0,001 & 20,71 & 0,004 \\
\hline
\end{tabular}

\begin{tabular}{|l|c|c|c|c|c|c|c|}
\hline & Ni & Al & V & Nb & Ti & Cu & Fe \\
\hline TP316H & 0,25 & 0,015 & 0,2 & 0,064 & - & - & Bāze \\
\hline Thermanīts & 11,13 & - & - & - & - & - & Bāze \\
\hline Nicro 82 & Bāze & - & - & 2,6 & 0,368 & 0,01 & 0,31 \\
\hline
\end{tabular}

4. TABULA

TĒRAUDU ĶİMISKO ELEMENTU SASTĀVS (MAS.\%)

\begin{tabular}{|c|c|c|c|c|c|c|c|c|}
\hline & $\mathbf{C}$ & $\mathbf{M n}$ & $\mathbf{P}$ & $\mathbf{S}$ & $\mathbf{S i}$ & $\mathbf{C r}$ & $\mathbf{N i}$ & $\mathbf{N}$ \\
\hline $\mathbf{3 0 4}$ & 0,08 & 2,00 & 0,045 & 0,03 & 0,75 & $18-20$ & $8,0-12,0$ & 0,1 \\
\hline $\mathbf{3 0 8}$ & 0,08 & 2,00 & 0,045 & 0,03 & 1,00 & $19-20$ & $10,0-12,0$ & 0,1 \\
\hline
\end{tabular}

5. TABULA

METĀLU ĶĪMISKO ELEMENTU SASTĀVS (MAS.\%)

\begin{tabular}{|c|c|c|c|c|c|c|c|c|c|c|c|c|}
\hline & $\mathbf{C}$ & $\mathbf{F e}$ & $\mathbf{T i}$ & $\mathbf{M n}$ & $\mathbf{P}$ & $\mathbf{S i}$ & $\mathbf{S}$ & $\mathbf{C r}$ & $\mathbf{N i}$ & $\mathbf{M o}$ & $\mathbf{C u}$ & $\mathbf{A l}$ \\
\hline $\mathbf{T i}$ & 0,20 & 0,32 & bāze & - & - & - & - & - & - & - & - & 0,20 \\
\hline $\begin{array}{c}\text { AISI } \\
\text { 304L }\end{array}$ & 0,01 & bāze & - & 1,15 & 0,045 & 0,23 & 0,09 & 21,20 & 8,42 & 0,03 & 0,09 & - \\
\hline
\end{tabular}

Karbīdu graudu veidošanās tēraudu rekristalizācijas procesā noteikta dzelzs sakausējumiem ar ķīmisko elementu sastāvu, kas parādīts 3. tabulā [13].

Sakausējumu uzkarsēšanas temperatūra bija 1322 un $1362^{\circ} \mathrm{C}$. Pēc metināšanas paraugus izturēja 1 stundu $750^{\circ} \mathrm{C}$. Šādos temperatūras režīmos tēraudā bija novērojamas graudu robežvirsmu izmaiņas un starpgraudu plaisu veidošanās. Tika konstatēta karbīdu $\mathrm{M}_{23} \mathrm{C}_{6}$, kur $\mathrm{M}$ ir $\mathrm{Cr}$ vai $\mathrm{Fe}$, un savienojumu $\mathrm{MX}$ veidošanās, kur $\mathrm{M}$ ir $\mathrm{V}$ vai $\mathrm{Nb}$, bet $\mathrm{X}$ ir $\mathrm{N}$ vai $\mathrm{C}$. Autori [13] norāda, ka tēraudu struktūrā atsevišķu reǵionu veidošanās ar rupjgraudu un sīkgraudu dal̦inām noris tērauda pamatfāžu transformācijas rezultātā pie augsttemperatūras slogojuma, kad migrējošu elementu atomi veido savienojumus. Plaisu veidošanos autori skaidro ar starpgraudu plīsumiem, kas tālāk veido plaisas.

Rekristalizācijas un metāla tā saucamā neatgriezeniskā „noguršana” (creep process) ir novērota arī Cr-Ni leǵētajos AISI/ASTM 304. un 308. markas tēraudos [14] ar ķīmisko elementu sastāvu, kas dots 4. tabulā.

Neskatoties uz l,oti līdzīgo ķīmisko elementu sastāvu un daudzumu, pētījumos novērota atšksirīga šo metālu sakausējumu neatgriezeniskā rekristalizācijas „noguruma” 
iestāšanās. 923K temperatūrā un nepārtraukta cikliska spiediena ietekmē 308. markas tērauds uzrādīja mazāku rekristalizācijas pretestību nekā 304. Plaisu veidošanās 304. un 308 markas tēraudu metinājumos tiek skaidrota ar dažādām rekristalizācijas un neatgriezeniska metāla noguruma norisēm. Izsmel̦ošākus pētījumus par šādu atšksirīgu norišu un plaisu veidošanos autori šajā rakstā nesniedz.

Būtiskāki pētījumu rezultāti par AISI 304. markas tērauda rekristalizāciju doti citā literatūras avotā [15]. Pētīts tērauds ar sekojošu k̦īmisko elementu sastāvu (mas.\%): C - 0,02; Mn 1,6; $\mathrm{Ni}-8,2 ; \mathrm{Cr}-18,5 ; \mathrm{Cu}-0,8$. Pēc tērauda paraugu $3 \mathrm{~min}$ ilgas karsēšanas $\operatorname{li} \mathrm{dz} 1200^{\circ} \mathrm{C}$, temperatūru kāpinot par $5^{\circ}$ sek., pēc tam atdzesējot līdz $850-1100^{\circ} \mathrm{C}$ un šādu temperatūru uzturot $2 \mathrm{~min}$, bet pēc tam uzliekot spiedes slogojumu no 50 līdz $250 \mathrm{MPa}$, tāpat novērota rekristalizācija, kura saistīta ar graudu lieluma un robežvirsmu izmaiņām.

Jaunu ķīmisku savienojumu veidošanās, kā elementu atomu difūzijas process, ir pētīta [16] karsēšanas procesā starp leǵēto tēraudu AISI 304L un titānu, kuru ķīmiskie sastāvi parādīti 5. tabulā.

Karsēšana šajos pētījumos realizēta kā eksplozīvs metināšanas process (detonācija $2400 \mathrm{~m} / \mathrm{s}$ ar blīvumu $850 \mathrm{~kg} / \mathrm{m}^{3}$ ). Pēc tam paraugi argona atmosfērā karsēti 1 stundu temperatūras intervālā no $650-950^{\circ} \mathrm{C}$. Novērota intermetalīdu slāņu, kuru biezums pieaug, paaugstinot temperatūru, veidošanās. Noteikts difūzijas slāṇu ķīmisko elementu sastāvs $650,750,850$ un $950^{\circ} \mathrm{C}$ un tas, ka Ti difüzija dzelzs sakausējumā ir lēnāka par $\mathrm{Fe}, \mathrm{Cr}$ un $\mathrm{Ni}$ atomu difūziju titānā. Pētījumu rezultātā konstatēts, ka $750^{\circ} \mathrm{C}$ veidojas trauslie intermetalītiskie savienojumi $\mathrm{FeTi}, \mathrm{Fe}_{2} \mathrm{Ti}$ un jauktais oksīds $\mathrm{Fe}_{2} \mathrm{Ti}_{4} \mathrm{O}$, bet temperatūras intervālā no $850^{\circ} \mathrm{C}$ līdz $950^{\circ} \mathrm{C}-$ $\mathrm{Fe}_{2} \mathrm{Ti}_{4} \mathrm{O}$ un trausli intermetalītiskie savienojumi FeTi, $\mathrm{Fe}_{2} \mathrm{Ti}$, $\mathrm{Cr}_{2} \mathrm{Ti}, \mathrm{NiTi}, \mathrm{TiFe}_{2,603} \mathrm{O}_{0,36}$.

Kā parāda literatūras dati, plaisu veidošanos tēraudu izstrādājumos nosaka gan mikroplaisu veidošanās starp sakausējumu graudiem, gan trauslo intermetalītisko savienojumu veidošanās atomu migrācijas procesos. Intermetalītisko savienojumu veidošanās, to lokalizēšanās konkrētā izstrādājuma visvairāk termiski un mehāniski slogotajās vietās, var būt cēlonis izstrādājuma lūšanai.

Intermetalīdu veidošanās tēraudos un vara sakausējumos sakarā ar izmainītu un daudzveidīgu jaunu ķīmisko elementu pielietošanu ir maz pētīta.

Vara sakausējumam ar 40 mas.\% Zn, kas nesatur leǵējošos elementus, ir raksturīgs trauslums. Tādēl, lai paaugstinātu misiņa mehānisko izturību, to leg̣ē ar $\mathrm{Pb}, \mathrm{Ni}, \mathrm{Fe}, \mathrm{Bi}$. Taču, neskatoties uz $\mathrm{Pb}$ daudzumu sakausējumā līdz 3,7 mas.\%, ir novērojama $\mathrm{Cu}-\mathrm{Zn}$ sakausējuma rekristalizācija un $\mathrm{Pb}$ viskeru augšana uz virsmas [17]. N̦emot vērā Eiropas direktīvas Nr.2002/95/EC „Inovatīvu, videi draudzīgu tehnologiju un produktu izstrādes stratēǵija un metodika" (RoHS) prasības par $\mathrm{Pb}$ pielietošanas maksimālu ierobežošanu un pat aizliegumu, ir izstrādāts jauns vara sakausējums [18] ar sekojošu ķīmisko elementu sastāvu (mas.\%): Zn - 40,86, Sn 0,$59 ; \mathrm{Pb}-0,005 ; \mathrm{Ni}-0,004 ; \mathrm{Fe}-0,23 ; \mathrm{Al}-0,005 ; \mathrm{Cr}-0,34$; $\mathrm{Bi}$ - līdz 2,85; Cu - bāzes metāls. Šāds iegūtais $\mathrm{Cu}-\mathrm{Zn}$ sakausējums satur 0,2-0,4 tilpuma procentus $\mathrm{Fe}-\mathrm{Cr}$ intermetalītiskā savienojuma $\mathrm{Cr}_{1,36} \mathrm{Fe}_{0,52}$, kas izveidojies karsēšanas procesā. Neskatoties uz intermetalīda klātbūtni, sakausējuma mehāniskās īpašības ir par 29\% augstākas, salīdzinot ar $\mathrm{Pb}$ saturošo $\mathrm{Cu}-\mathrm{Zn}$ sakausējumu. Citu $\mathrm{Cu}-\mathrm{Zn}$ intermetalīdu veidošanās sakausējumā šajā gadījumā nav noteikta.

Citu autoru pētījumos [19] pēc Cu-Zn sakausējuma (ar Zn daudzumu 48,7 mas.\%) 15 min ilgas karsēšanas pie $500^{\circ} \mathrm{C}$ tā $\beta$ fāzē, kuras struktūra ir sānu skaldnēs centrēts kubs, novērota tilpumā centrētas kubiskas kristālu struktūras veidošanās. Ar rentgenfāžu analīzi noteiktas fāžu sastāva izmaiṇas gan pēc 48 stundu ilga mehāniskā slogojuma, gan 15 minūšu ilgas karsēšanas $500^{\circ} \mathrm{C}$. Darbā tomēr nav dota analīze, kādi savienojumi ir veidojušies, kas nosaka izmaiñas rentgenogrammā, kā arī nav dota struktūras salīdzinošā metalogrāfiskā analīze pirms un pēc sakausējuma mehāniskā un termiskā slogojuma.

Intermetalītisko savienojumu fāžu klātbūtne ir noteikta $\mathrm{Cu}-$ $\mathrm{Zn}$ sakausējumā, kas iegūts $300^{\circ} \mathrm{C}$ no $\mathrm{Cu}$ un $\mathrm{Zn}$, tiem pievienojot $\mathrm{Fe}, \mathrm{Si}, \mathrm{Al}$ un $\mathrm{P}, \mathrm{ka} \mathrm{CuFe}, \mathrm{CuSi}, \mathrm{CuAl}$ un $\mathrm{CuP}$ sakausējumus [20]. Karsēšanā iegūts tipiskais $\alpha+\beta^{\prime}$ kausējums. $\beta^{\prime}$ fāzes dal̦ā ir novērotas izmain̦as, ko autori skaidro ar dažādo silīcija un alumīnija daudzumu pie samazinātā $\mathrm{Zn}$ daudzuma šajā fāzē. Rentgenogrāfiskā analīze liecina par $\mathrm{Fe}_{\mathrm{x}} \mathrm{Si}_{\mathrm{y}}$ un $\mathrm{CuZn}_{\mathrm{y}}$ intermetalīdu klātbūtni. Tālākie pētījumi parādījuši intermetalīdu ietekmi uz sakausējuma termofizikālajām īpašībām.

Kā liecina literatūras dati, trauslo ķīmisko un intermetalītisko savienojumu veidošanās tēraudos un vara sakausējumos, tos termiski un mehāniski slogojot, ir maz pêtīta. Tajā pašā laikā dzelzs sakausējumu rekristalizācijas procesos pie atomu savstarpējās difūzijas un starpgraudu mikroplaisu veidošanās, trauslo ķīmisko un intermetalītisko savienojumu papildus veidošanās var būtiski ietekmēt sakausējumu mehāniskās īpašības - izraisīt to plaisāšanu un lūšanu.

Piln̄̄gi jauni un fragmentāri ir pētījumi par intermetalīdu veidošanos $\mathrm{Cu}-\mathrm{Zn}$ sakausējumos, atkarībā no ķīmisko elementu sastāva, gan šo sakausējumu iegūšanā, gan tos termiski un mehāniski slogojot.

Šie uzskaitīitie faktori nosaka nepieciešamību veikt detalizētus un sistematizētus metalogrāfiskos, struktūru un rentgenfāžu pētījumus par trauslo ķīmisko un intermetalītisko savienojumu veidošanos dzelzs un vara sakausējumos atkarībā no to ķīmisko elementu sastāva, lai sakausējumu pareiza izvēle pie konkrēta termiskā un mehāniskā slogojuma novērstu plaisāšanu un lūšanu.

\section{EKSPERIMENTĀLĀ DAL̦A}

Metālu sakausējumu struktūra, to neviendabība, kurā atklājas izmainītu struktūru joslas, bloki vai atsevišķu polikristālisku graudu grupas, pētīta ar metalogrāfijas mikroskopu XJL-17 (1600×) pie palielinājuma 400-800×. Struktūru analīzē lietoti metāla sakausējumiem raksturīgie metālu struktūru iekodināšanas šķ̄īdumi. Struktūras fotografētas caur mikroskopu uz 30 megapikseḷu jutības filmām, to skaitā - krāsainām. Struktūru rentgenfāžu analīze un intermetalīdu identificēšana veikta ar iekārtu A D8 ADVANCE Bruker AXS GMBH, kas apgādāta ar programmu DIFFRAC plus Evaluation Package Release 2007-EVA V13. Metālu k̦īmisko elementu sastāvs noteikts ar iekārtu „Bruker S4 PIONEER XRF Spektrometer", lietojot dzelzs un vara 
sakausējumu standartus ar noteiktu ķīmisko elementu daudzumu.

\section{REZULTĀTI UN TO IZVĒRTĒJUMS}

Intermetalītisko un ķīmisko savienojumu veidošanās dzelzs sakausējumos

Lai noskaidrotu intermetalītisko un k̦īmisko savienojumu veidošanās dzelzs sakausējumos, kā pētāmo paraugu izmantoja $250 \mathrm{~mm}$ garu dzelzs sakausējuma stieni ar $25 \mathrm{~mm}$ diametru. Izmantojot rūpniecisko lieces tehnoloǵiju, stieni karsēja no 3 līdz 5 min metālu griešanas gāzes degḷa liesmā temperatūrā pie $\sim 1200^{\circ} \mathrm{C}$. Šajā gadījumā stienis neliecās, bet salūza. Lai noteiktu lūšanas cēloṇus, tika veikta sakausējuma ķīmiskā sastāva analīze.

Veiktā metāla sakausējuma struktūras analīze tuvināti lūzuma vietai ar šksērsšlifu mikroskopijas metodi pēc virsmas spoguḷpulēšanas un iekodināšanas etilspirta-slāpekḷskābes šķīdumā, parādīja atšksirīgus norobežotus polikristālisku graudu blokus (1.a,b,c att.), kas pēc savas struktūras būtiski atšksiras no sakausējuma struktūras.

Kā liecina veiktie rentgenfāžu analī̌̌u pētījumu, šādu norobežotu, neviendabīgu sakausējuma strukūru nosaka lielā daudzumā esošu dzelzs-volfrāma-oglekḷa $\mathrm{Fe}_{3} \mathrm{~W}_{3} \mathrm{C}+\mathrm{Fe}_{4} \mathrm{~W}_{2} \mathrm{C}$ un mazākā daudzumā - dzelzs-molibdena-ogleklı $\mathrm{Fe}_{3} \mathrm{Mo}_{3} \mathrm{C}$ un $\mathrm{Fe}_{3} \mathrm{C}$ savienojumu veidošanās karsēšanas procesā (2.att.).

Mazāk norobežotas, atšķirīgas struktūras veidošanos (1.d,e att.) iespējams nosaka šo savienojumu kā atsevišķu graudu veidošanās mazākā daudzumā starp dzelzs sakausējuma graudiem.

Šādu jaunu savienojumu veidošanās sakausējumos, tos termiski slogojot, sākas un noris elementu atomu savstarpējās difūzijas rezultātā uz sakausējumu kristālu graudu robežvirsmām.

6. TABULA

PĒTĀMĀ PARAUGA ĶĪMISKO ELEMENTU SASTĀVS (MAS.\%)

\begin{tabular}{|c|c|c|c|c|c|c|c|c|c|c|c|}
\hline $\mathbf{C}$ & $\mathbf{S i}$ & $\mathbf{M n}$ & $\mathbf{N i}$ & $\mathbf{C r}$ & $\mathbf{M o}$ & $\mathbf{W}$ & $\mathbf{V}$ & $\mathbf{C u}$ & $\mathbf{S}$ & $\mathbf{P}$ & $\mathbf{F e}$ \\
\hline 0,17 & 0,465 & 0,485 & 0,28 & 3,93 & 4,92 & 5,28 & 1,92 & 0,17 & 0,006 & $<0,01$ & 82,3 \\
\hline
\end{tabular}
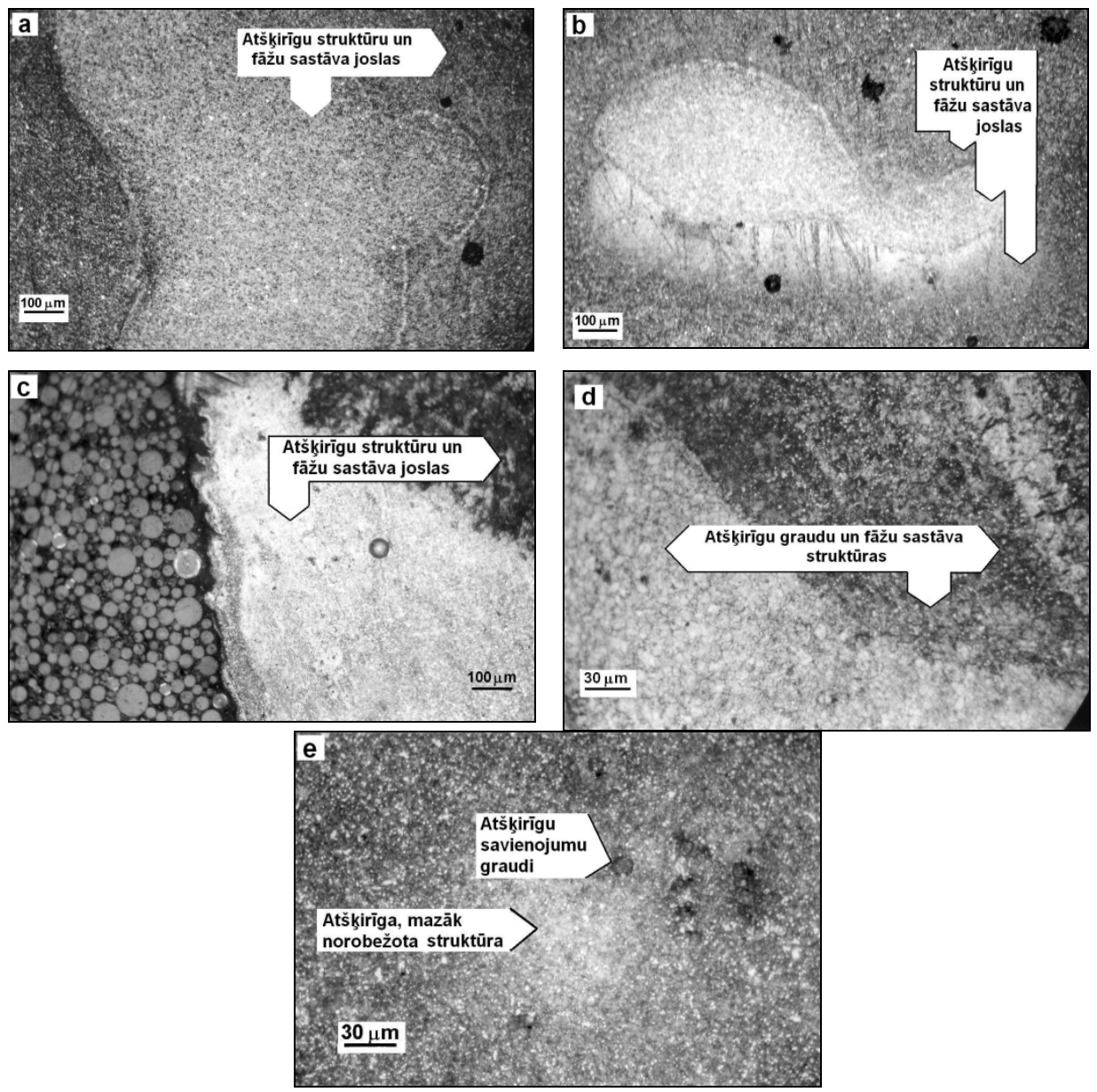

1. att. Atšķirīgu, norobežotu (a,b,c) un mazāk norobežotu $(\mathrm{d}, \mathrm{e})$ polikristālisku graudu bloku neviendabīgas struktūras raksturojums. 


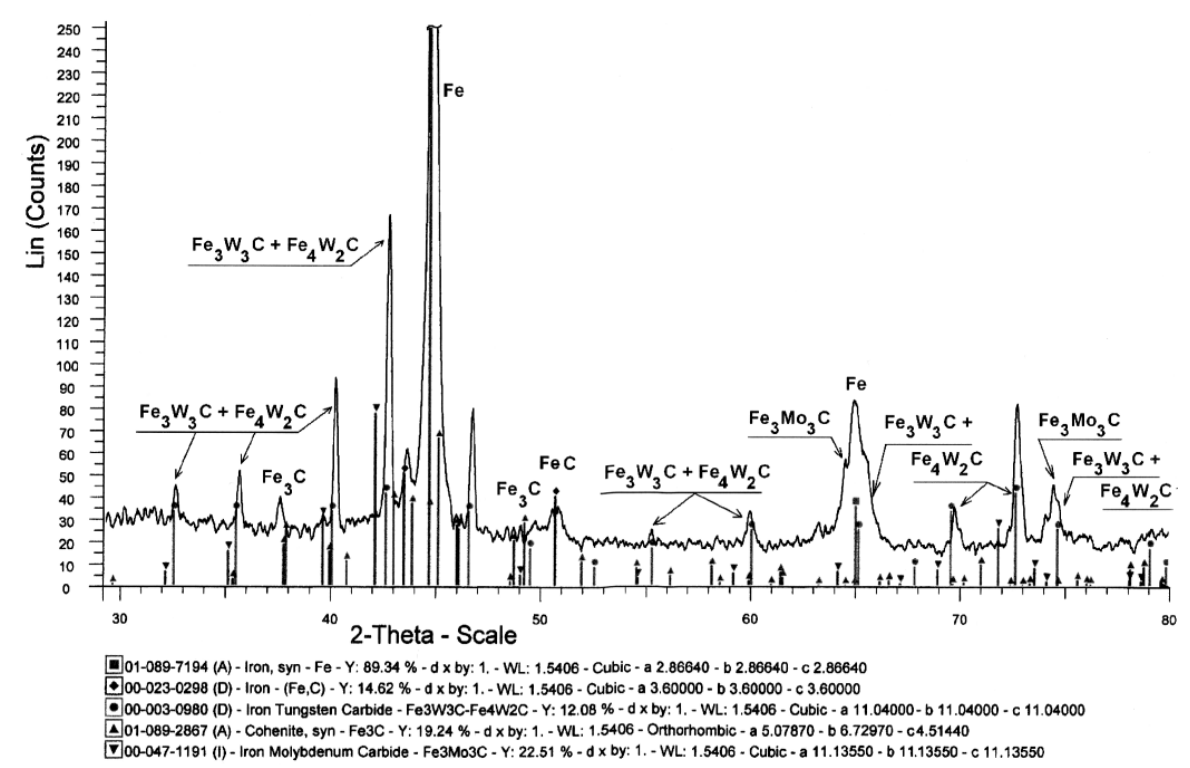

2. att. Norobežoto atšķirīgo struktūru - polikristālisko graudu bloku fāžu sastāva raksturojošã rentgenogramma.

7. TABULA

METĀLA VIRSMAS K̦īMISKO ELEMENTU SASTĀVS (MAS.\%): 1. PIRMS VIZUĀLI REDZAMĀM IZMAIṆĀM; 2. PĒC REKRISTALIZĀCIJAS

\begin{tabular}{|c|c|c|c|c|c|c|c|c|c|c|c|c|}
\hline $\begin{array}{c}\text { Metāla } \\
\text { virsmas } \\
\text { slānis }\end{array}$ & $\mathbf{C}$ & $\mathbf{O}$ & $\mathbf{S i}$ & $\mathbf{M n}$ & $\mathbf{N i}$ & $\mathbf{C r}$ & $\mathbf{M o}$ & $\mathbf{V}$ & $\mathbf{C u}$ & $\mathbf{S}$ & $\mathbf{A l}$ & $\mathbf{F e}$ \\
\hline 1. & 0,56 & - & 0,23 & 0,62 & 0,06 & 1,39 & 0,74 & 0,30 & 0,07 & 0,02 & 0,05 & bāze \\
\hline 2. & $1,50-1,6$ & 2,04 & $0,73-0,89$ & 0,47 & 0,054 & 1,08 & 0,56 & 0,23 & 0,06 & 0,09 & & bāze \\
\hline
\end{tabular}
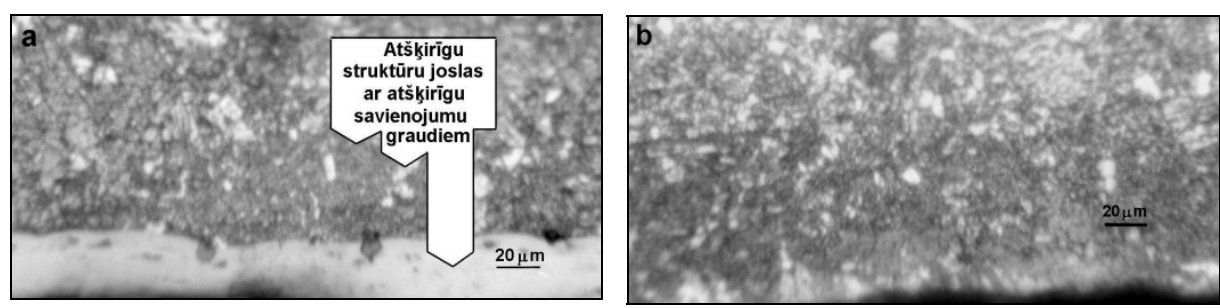

3.att. Metāla rekristalizācijas neviendabīgas struktūras veidošanās raksturojums parauga šḳērsgriezumā.

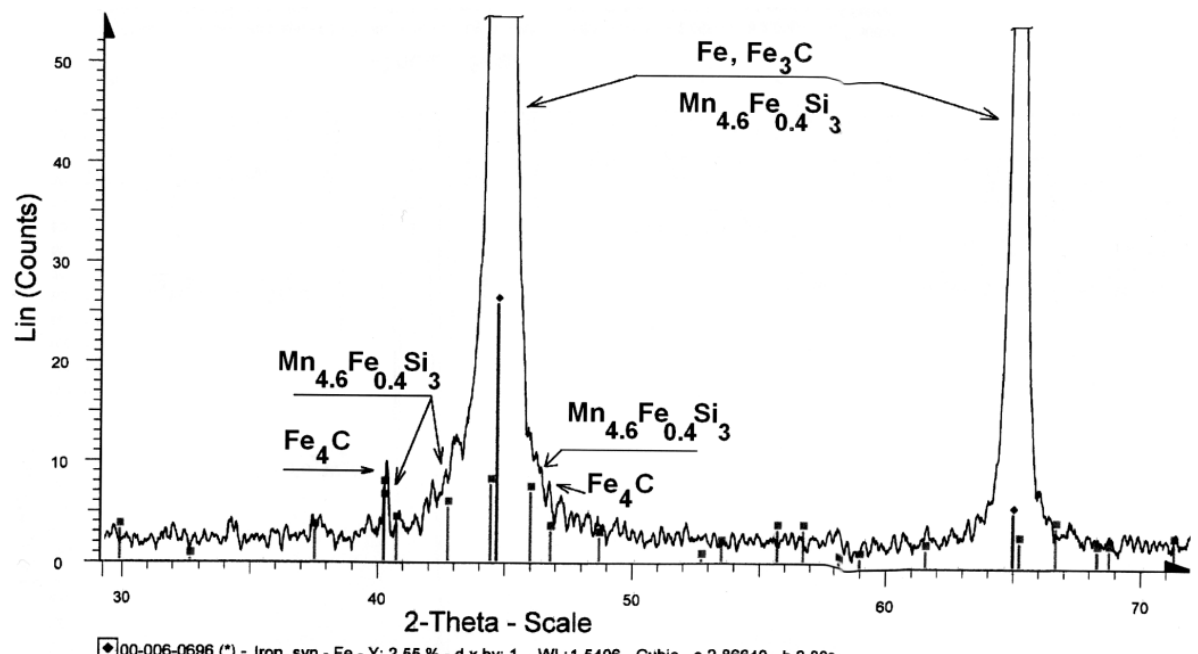

00-006-0696 (") - Iron, syn - Fe - Y: $2.55 \%$ - d x by: 1. - WL: 1.5406 - Cubic - a 2.86640 - b 2.86640 - c 2.86640

00-046-1314 (Q) - Unnamed mineral (NR) - Mn4.6Fe0.4Si3 - Y: 0.74 \% - $d x$ by: 1. - WL: 1.5406 - Hexagonal - a 6.88800 - b 6.88800 - c 4.80200 口03-065-5723 (I) - Iron Carbide - Fe4C - Y: 0.72 \% - d x by: 1. - WL: 1.5406 - Cubic - a 3.87800 - b 3.87800 - c 3.87800

4.att. Metāla rekristalizācijas neviendabīgās struktūras fāžu sastāva raksturojums. 

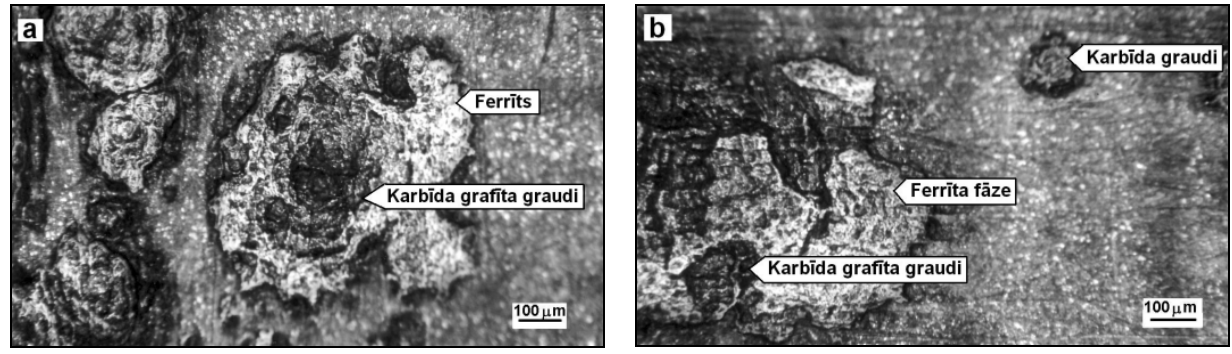

5.att. Karbīda graudu un oglekḷa - grafita izdalīšanos raksturojošie metāla virsmas struktūrattēli.

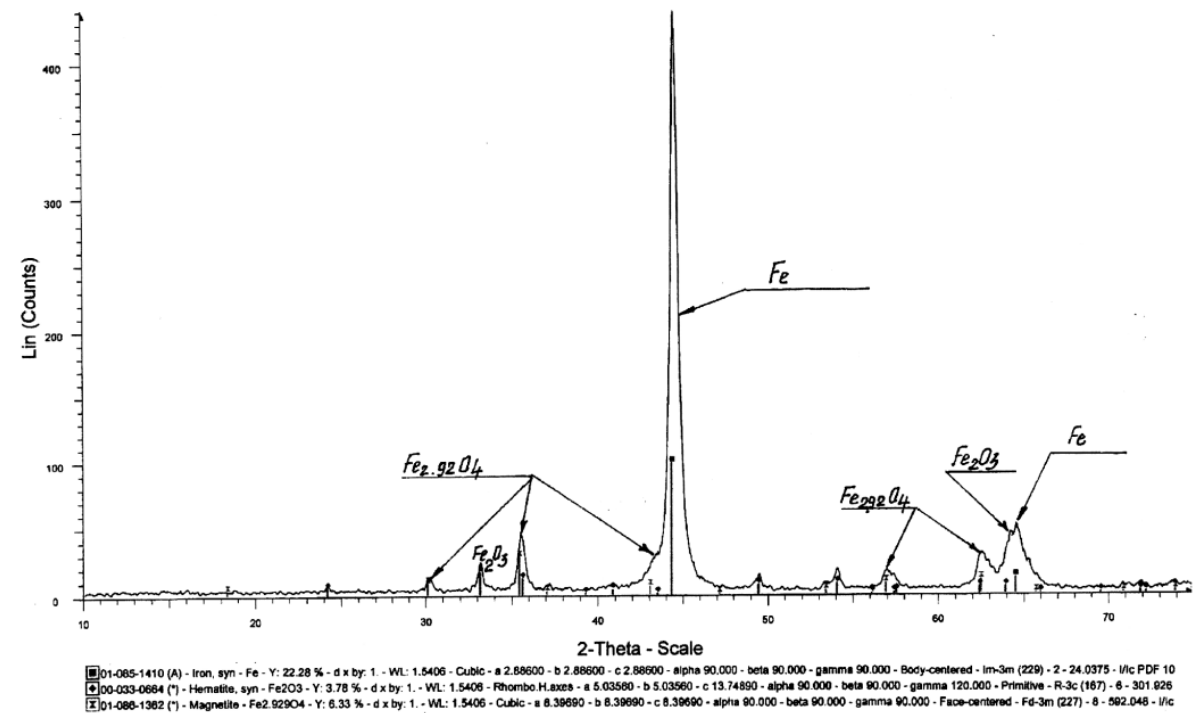

6.att. Metāla fāžu sastāva raksturojošā rentgenogramma pēc rekristalizācijā radušos pelēki-melno savienojumu notīrišanas.

8. TABULA

METĀLA VIRSMAS ĶİMISKO ELEMENTU SASTĀVS (MAS.\%): 1. PIRMS VIZUĀLI REDZAMĀM IZMAIN̦ĀM; 2. PĒC REKRISTALIZĀCIJAS

\begin{tabular}{|c|c|c|c|c|c|c|c|c|c|c|c|c|}
\hline $\begin{array}{c}\text { Metāla } \\
\text { virsmas } \\
\text { slānis }\end{array}$ & $\mathbf{C}$ & $\mathbf{O}$ & $\mathbf{S i}$ & $\mathbf{M n}$ & $\mathbf{N i}$ & $\mathbf{C r}$ & $\mathbf{M o}$ & $\mathbf{V}$ & $\mathbf{C u}$ & $\mathbf{S}$ & $\mathbf{P}$ & $\mathbf{N b}$ \\
\hline 1. & 0,58 & - & 0,22 & 0,48 & 0,40 & 10,35 & 0,6 & 0,15 & 0,074 & 0,08 & 0,02 & 0,33 \\
\hline 2. & 1,98 & 25,3 & 2,22 & 0,33 & 0,246 & 7,22 & 0,423 & 0,10 & 0,05 & 0,19 & 0,02 & 0,23 \\
\hline
\end{tabular}
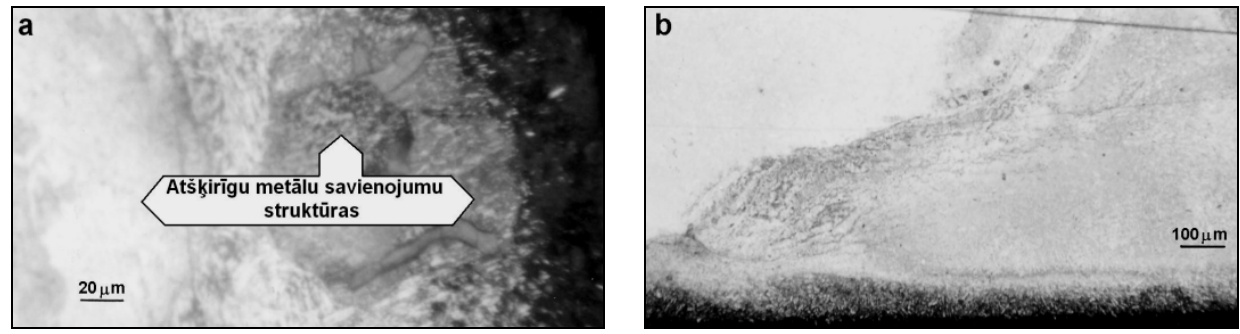

7.att. Atšķirīgu, norobežotu un mazāk norobežotu polikristālisku graudu struktūras raksturojums.

Atomu savstarpējās difūzijas rezultātā veidojas vakances un tukšumi graudos, kas savukārt paātrina šo atomu difūzijas procesus graudu tilpumā un sekmē starpgraudu mikroplaisu veidošanos [21]. Papildus trauslo intermetalītisko-ķīmisko savienojumu graudu veidošanās, kas šajā gadījumā ir $\mathrm{Fe}_{3} \mathrm{~W}_{3} \mathrm{C}$, $\mathrm{Fe}_{4} \mathrm{~W}_{2} \mathrm{C}, \quad \mathrm{Fe}_{3} \mathrm{Mo}_{3} \mathrm{C}$ un $\mathrm{Fe}_{3}$, rada priekšnoteikumus sakausējuma trauslumam un tā lūšanai, mehāniski slogojot $[21,22]$.
Līdzīga intermetalītisko un ķīmisko savienojumu veidošanās rekristalizācijas rezultātā $500^{\circ} \mathrm{C}$ un pie $\sim 4500$ stundu ilga mehāniskā slogojuma, noteikta citam paraugam ar atšķirīgu ķ̄imisko elementu sastāvu (7.tab. 2.poz.).

Kā parāda šksērsstruktūru mikroskopijas attēli izstrādājuma daļai bez vizuāli redzamām izmaiñām metāla virsmā (7.tab. 1.poz.), tā struktūra ir neviendabīga, tajā redzami atšķirīgu metāla savienojumu graudi (3.a,b att.). 
Virsmas ārējā slānī veidojas atškirīga biezuma oksīdu kārtina. Rentgenfāžu analīze (4.att.) parāda, ka metālā ir veidojušies un notikusi savienojumu $\mathrm{Mn}_{4,6} \mathrm{Fe}_{0,4} \mathrm{Si}_{3}, \mathrm{Fe}_{3} \mathrm{C}, \mathrm{Fe}_{4} \mathrm{C}$ graudu augšana.

Izstrādājuma daļā, kurā bez temperatūras slogojuma ir bijis paaugstināts mehāniskais spiediens, rekristalizācija ir noritējusi intensīvāk. Mikroskopijas attēli (5.a,b att.) parāda struktūras izmainas metālā ar karbīda graudu izdalīšanos uz virsmas un to tālāku sadalīšanos, rentgenamorfā grafìta izdalīšanos, kā rezultātā izmainās dzelzs sakausējuma pamatstruktūra. Ap šiem grafìta graudiem veidojas ferrīta fāze. Kā parāda tālākie virsmu analīžu rezultāti, līdz̄igi noris savienojuma $\mathrm{Mn}_{4,6} \mathrm{Fe}_{0,4} \mathrm{Si}_{3}$ sadalīšanās ar Si izdalīšanos. Šādu rekristalizācijas procesa norisi apstiprina virsmas ķīmisko elementu sastāva analīžu dati (7.tab., 2.pozīcija salīdzinājumā ar 1.poz.), kas parāda ievērojamu C un Si daudzuma pieaugumu slānī. Skābekḷa piesaiste virsmas slānī raksturo tā oksidēšanos. Karbīda graudu sadalī̌sanās ar rentgenamorfu $\mathrm{C}$ un $\mathrm{Si}$ veidošanos ir novērojama vizuāli kā neviendabīgs pelēki-melns virsmas slānis. Rekristalizācijas procesu ar karbīda un silīcija savienojumu izdalīšanos apstiprina rentgenfāžu diagramma metāla virsmai pēc pelēki-melnā slāņa noņemšanas. Tā parāda, ka metāla virsmas fāžu sastāvs ir ievērojami izmainīts. Metāls vairs nesatur $\mathrm{Fe}_{3} \mathrm{C}, \mathrm{Fe}_{4} \mathrm{C}$ un $\mathrm{Mn}_{4,6} \mathrm{Fe}_{0,4} \mathrm{Si}_{3}$ (6.att.).

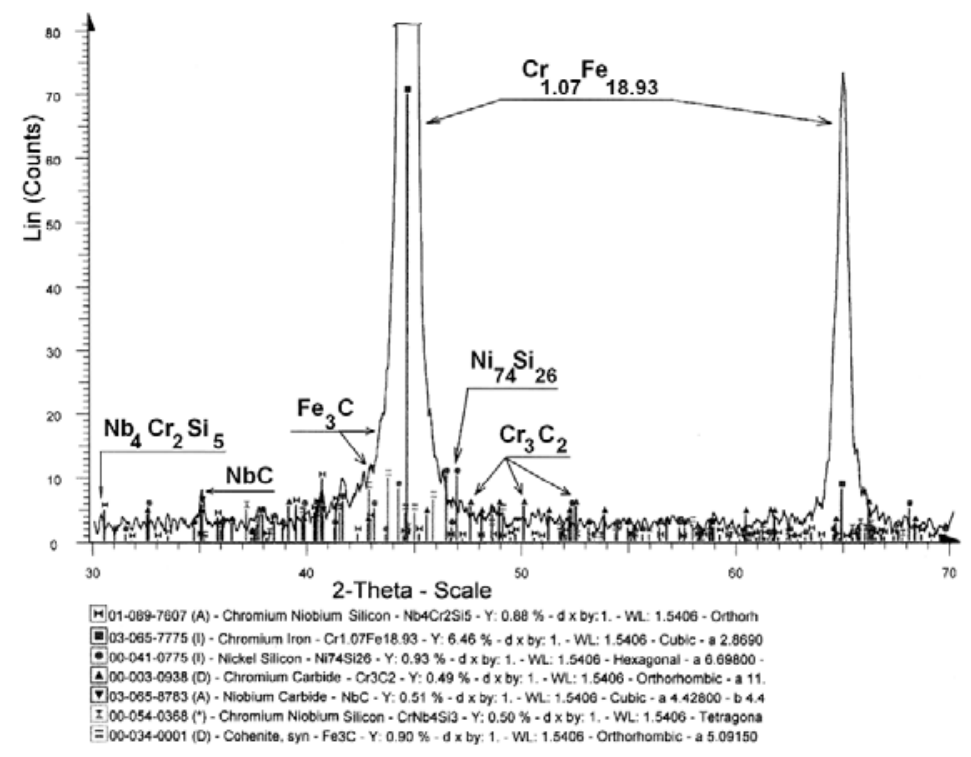

8.att. Norobežotās, atšķirīgās polikristāliskās graudu struktūras fāžu sastāvu raksturojošā rentgenogramma.
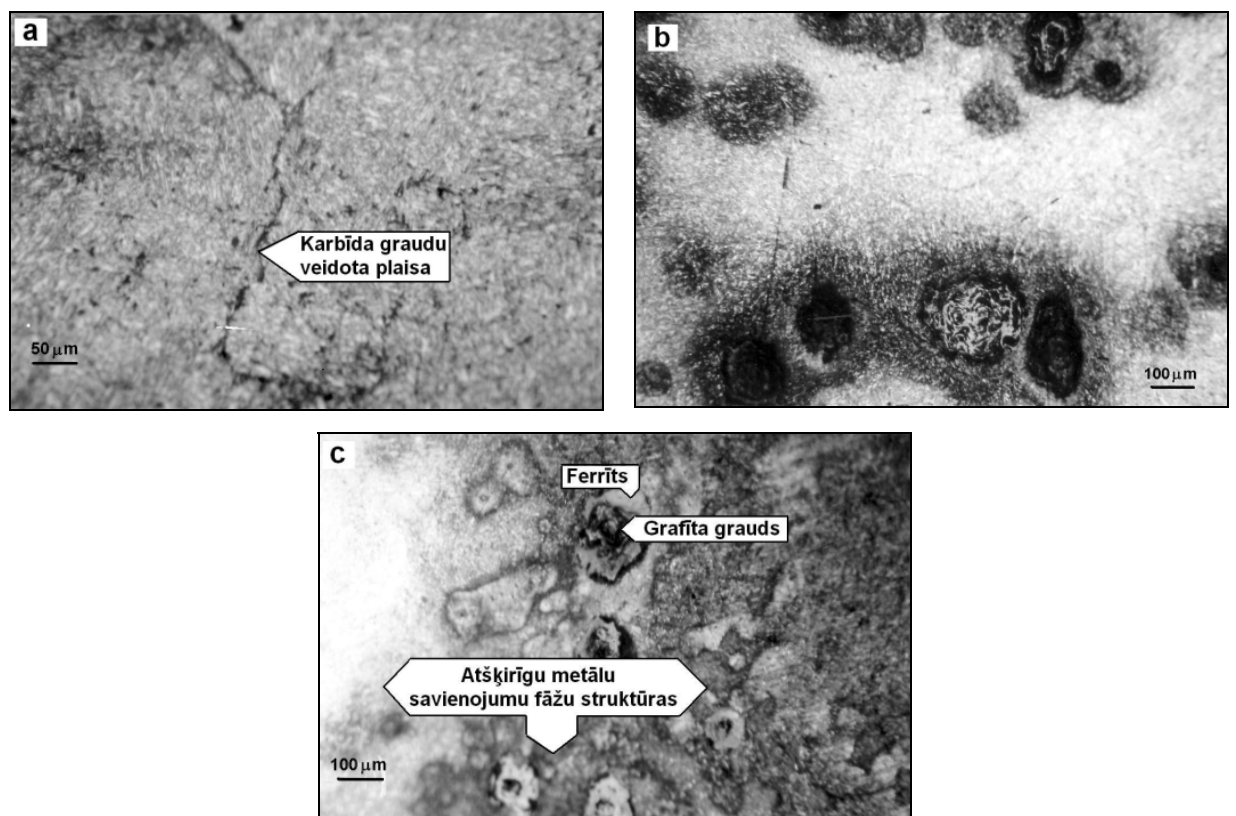

9.att. Karbīda graudu augšana uz dzelzs sakausējumu graudu robežvirsmām, to veidotā plaisa (a) un grafīta izdalīšanās (b), ferrīta fāzes veidošanās ap grafîta graudiem. 
Neskatoties uz dzelzs sakausējuma legéjumu ar ievērojami paaugstinātu $\mathrm{Cr}$ daudzumu un $\mathrm{Nb}$ pievienošanu, arī šajā gadījumā notikusi sakausējuma rekristalizācija ar ķīmisko elementu un fāžu sastāva izmaiņām virsmas slān̄̄ pie 4500 stundu ilga slogojuma $500^{\circ} \mathrm{C}$.

Kā parāda mikroskopijas attēli (7.a,b att.), gan virsmas virsējā slānī, gan attālināti no parauga malas metāla dzil̦umā, ir redzamas ievērojamas struktūras izmaiņas. Mikroskopijas attēli atklāj lielu, atškiirīgu metāla savienojumu fāžu joslas ar atškirīgiem metālu graudiem.

Rentgenfāžu analižu rezultāti liecina (8.att.), ka metāla sakausējumam rekristalizējoties, tajā ir veidojusies virkne savienojumu - $\mathrm{Cr}_{1,07} \mathrm{Fe}_{18,93}, \mathrm{Fe}_{3} \mathrm{C}, \mathrm{NbC}, \mathrm{Ni}_{74} \mathrm{Si}_{26}$ un $\mathrm{Nb}_{4} \mathrm{Cr}_{2} \mathrm{Si}_{5}$. Arī šajā gadījumā izstrādājuma dal̦ā, kurā bez ilgstoša temperatūras slogojuma pie paaugstināta ilgstoša mehāniskā slogojuma ir turpinājusies rekristalizācija.

Metāla sakausējuma dziḷās rekristalizācijas rezultātā, līdzīgi kā iepriekšējam sakausējuma paraugam, noris karbīda graudu, un no tiem oglekḷa izdalīšanās, kā arī Si graudu izdalīšanās no silīciju saturošajiem savienojumiem uz metāla parauga virsmas, kas būtiski izmaina metāla struktūru (9.att.).

Šādu rekristalizācijas procesa gaitu sakausējuma paraugā ar paaugstinātu $\mathrm{Cr}$ daudzumu un $\mathrm{Nb}$ klātbūtni apstiprina virsmas ķīmisko elementu analīze (8.tab. 2.poz.), kas parāda ievērojamu oglekḷa un silīcija daudzuma pieaugumu un, sakarā ar virsmas oksidēšanos, skābekḷa piesaisti līdz 25,3 mas.\%. Sakarā ar karbīdu un silīcija savienojumu izdrupšanu no virsmas virskārtā ir samazinājies $\mathrm{Cr}, \mathrm{Ni}, \mathrm{Mo}$, $\mathrm{V}, \mathrm{Nb}$ ķīmisko elementu daudzums pēc pelēki melnā slāṇa noṇemšanas.

Sakausējuma slāṇa rentgenfāžu analīze parāda, ka metāls, notiekot rekristalizācijai, ir zaudējis savu kristālisko struktūru, tas ir it kā ,kusis”, kas liecina par neatgriezenisku metāla „nogurumu” vai t.s. Creep procesa norisi - metāla sakausējuma struktūras sabrukšanu (10.att. salīdzinājumā ar 8.att.).

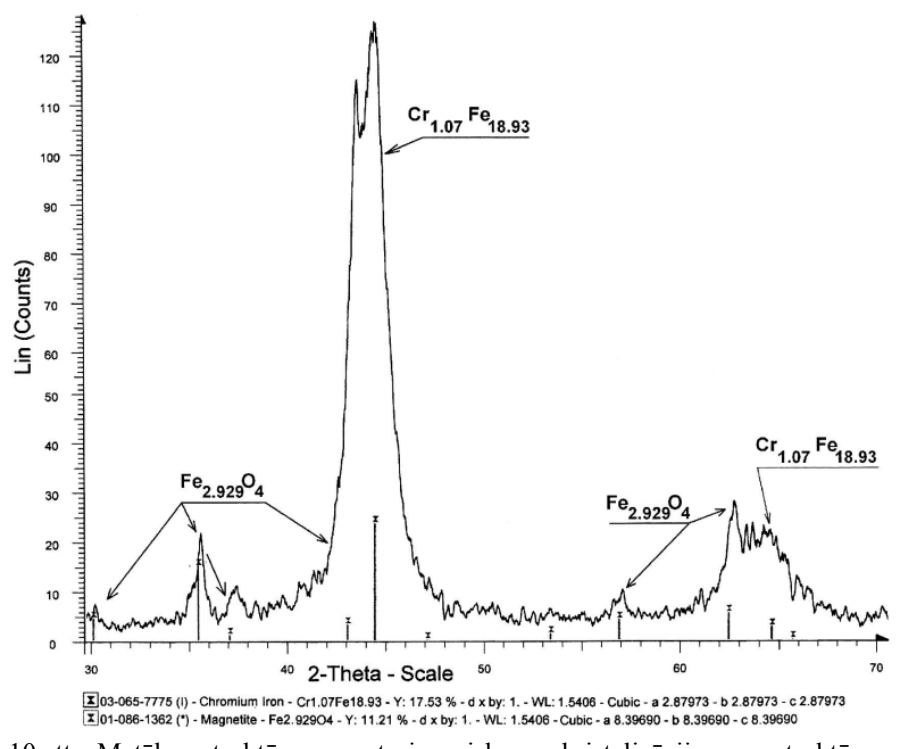

10.att. Metāla struktūras neatgriezenisko rekristalizāciju - struktūras sabrukšanu raksturojošā rentgenogramma.

Kā parāda iegūtie rezultāti, $\mathrm{Cr}$ daudzuma paaugstināšana $l \overline{\mathrm{d}} \mathrm{z} 10,35$ un $\mathrm{Nb}$ pievienošana $\operatorname{li} \mathrm{dz} \quad 0,33$ mas.\% nenovērš dzelzs sakausējumu rekristalizāciju ar karbīdu un citu k̦īmisko savienojumu veidošanos uz graudu robežvirsmām, to izdalī̌sanos uz metāla paraugu virsmas, mikroplaisu veidošanos starp graudiem un visā struktūrā, kas ir struktūras izmaiṇu un sabrukšanas cēlonis (9.a.att.) [21].

Šāda karbīdu graudu un oglekḷa izdalīšanās no dzelzs sakausējumiem ir stingri kontrolējama un limitējama ar $\mathrm{Cr}$, Mo, Co, Ti pievienošanu. Grafìta izdalīšanās rezultātā metāla struktūras izmainas, papildus tā trauslumam, rada izstrādājuma biezuma samazināšanos, kas var būt viens no lūšanas cēloniem.

Salīdzinājumā ar citu autoru iegūtajiem rezultātiem, pētot sakausējumus ar līdzīgu ķīmisko elementu sastāvu [10, 11], mūsu pētījumu novitāte ir detalizēti izsekotas ķīmisko elementu un fāžu sastāva izmaiñas dzelzs sakausējumos atbilstoši mikroskopijas attēlos redzamajām struktūru izmain̄ām, kas deva iespēju noteikt ne tikai karbīdu, bet papildus arī $\mathrm{Ni}, \mathrm{Cr}, \mathrm{Fe}, \mathrm{Si}$ ķīmisko un intermetalītisko savienojumu veidošanos atkarībā no sakausējuma elementu sastāva.

Metālu mikrogrāfijas attēlos redzamo struktūru izmaiņu analīze veikta, pamatojoties uz metālu analī̌̌u datiem enciklopēdiskajā izdevumā ,Metallographie” [23].

Intermetalītisko savienojumu veidošanās vara-cinka sakausējumos

$\mathrm{Cu}-\mathrm{Zn}$ sakausējumiem - misiņiem bez leg̣ējošo elementu klātbūtnes, ja Zn daudzums sakausējumā ir virs 20 mas.\%, piemīt trauslums, kas pieaug, Zn daudzumam palielinoties līdz 40 mas.\%. Pie šādas $\mathrm{Cu}$ un $\mathrm{Zn}$ attiecības sakausējums veidojas no divām fāzēm, t.i., $\alpha$ fāzes, kas ir $\mathrm{Cu}$ un $\mathrm{Zn}$ sakausējuma cietais šksīdums $\mathrm{Cu}_{0,64} \mathrm{Zn}_{0,36}$ ar skaldnēs centrēta kuba struktūru, un $\beta^{\prime}$ fāzes, kas ir intermetalītiskais elementu savienojums ar tilpumā centrēta kuba struktūru. $\beta^{\prime}$ fāzes pieaugums sakausējumā ar Zn daudzuma 40 mas.\% arī nosaka $\mathrm{Cu}-\mathrm{Zn}$ sakausējuma trauslumu. Lai novērstu $\mathrm{Cu}-\mathrm{Zn}$ sakausējumu patvalīgo plaisāšanu zemās temperatūrās un paaugstinātu to mehānisko stiprību, tiem parasti pievieno $\mathrm{Fe}$, $\mathrm{Mn}, \mathrm{Pb}, \mathrm{Ni}, \mathrm{Si}$ - kopā līdz 7,0-8,0 mas.\%.

Sakarā ar vispārējo tendenci ekonomēt leǵējošos elementus, lai spriestu par šāda samazināta leǵējošo elementu daudzuma ietekmi uz $\mathrm{Cu}-\mathrm{Zn}$ sakausējuma trauslumu, veikti sakausējumu pētījumi, kuru ķīmisko elementu saturs un sastāvs parādīts 9.tabulā.

Kā liecina sakausējuma parauga mikroskopiskā analīze (11.att.), struktūrā līdz ar $\alpha$ un $\beta^{\prime}$ fāzes kristāliem ir redzami trešās fāzes kristālu graudi.

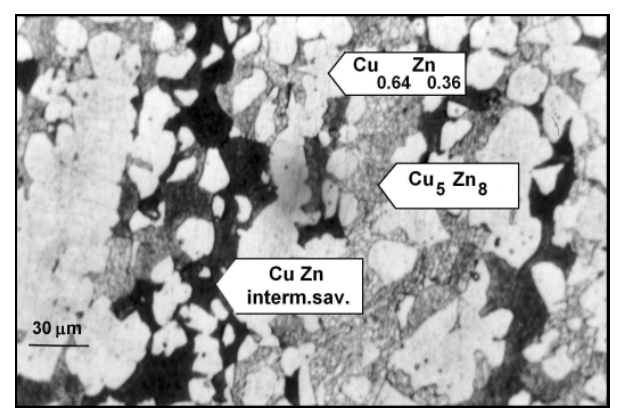

11.att.Vara-cinka sakausējuma struktūras raksturojums pie samazināta leǵējošo elementu daudzuma. 
9. TABULA

VARA-CINKA SAKAUSĒJUMA ĶĪMISKO ELEMENTU SASTĀVS AR SAMAZINĀTU LEĢĒJOŠO ELEMENTU DAUDZUMU (MAS.\%)

\begin{tabular}{|c|c|c|c|c|c|c|c|}
\hline $\mathbf{C u}$ & $\mathbf{Z n}$ & $\mathbf{P b}$ & $\mathbf{S n}$ & $\mathbf{N i}$ & $\mathbf{F e}$ & $\mathbf{S}$ & $\begin{array}{c}\text { Kopējais leǵejēošo } \\
\text { elementu daudzums }\end{array}$ \\
\hline 57,82 & 39,65 & 1,90 & 0,20 & 0,10 & 0,34 & 0,05 & 2,44 \\
\hline
\end{tabular}

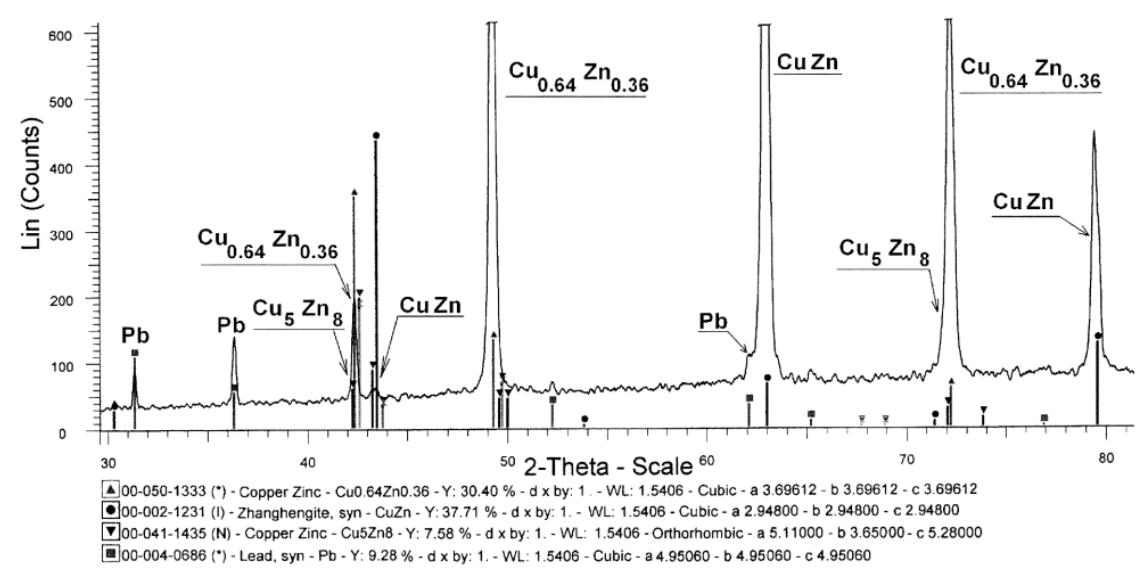

12.att. Vara-cinka sakausējuma ar samazinātu legéejošo elementu daudzumu fāžu sastāva raksturojošā rentgenogramma.

10. TABULA

VARA-CINKA SAKAUSĒJUMA K̦İMISKO ELEMENTU SASTĀVS AR PAAUGSTINĀTU LEĢĒJOŠO ELEMENTU DAUDZUMU (MAS.\%)

\begin{tabular}{|c|c|c|c|c|c|c|c|c|c|c|c|}
\hline $\mathbf{C u}$ & $\mathbf{Z n}$ & $\mathbf{N i}$ & $\mathbf{A l}$ & $\mathbf{P b}$ & $\mathbf{S n}$ & $\mathbf{F e}$ & $\mathbf{M n}$ & $\mathbf{C r}$ & $\mathbf{S i}$ & $\mathbf{P}$ & $\begin{array}{c}\text { Kopējā leg. } \\
\text { elementu saturs }\end{array}$ \\
\hline 57,44 & 38,0 & 0,375 & 0,37 & 2,53 & 0,72 & 0,472 & 0,03 & 0,014 & 0,032 & 0,015 & 4,53 \\
\hline
\end{tabular}
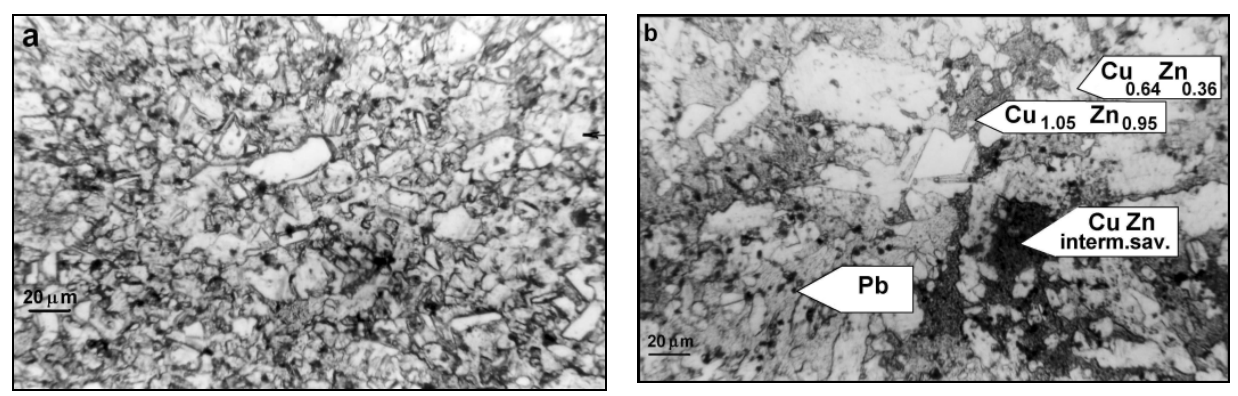

13.att. Cu-Zn sakausējuma struktūras raksturojums pie tā legéejuma ar 9 elementiem.

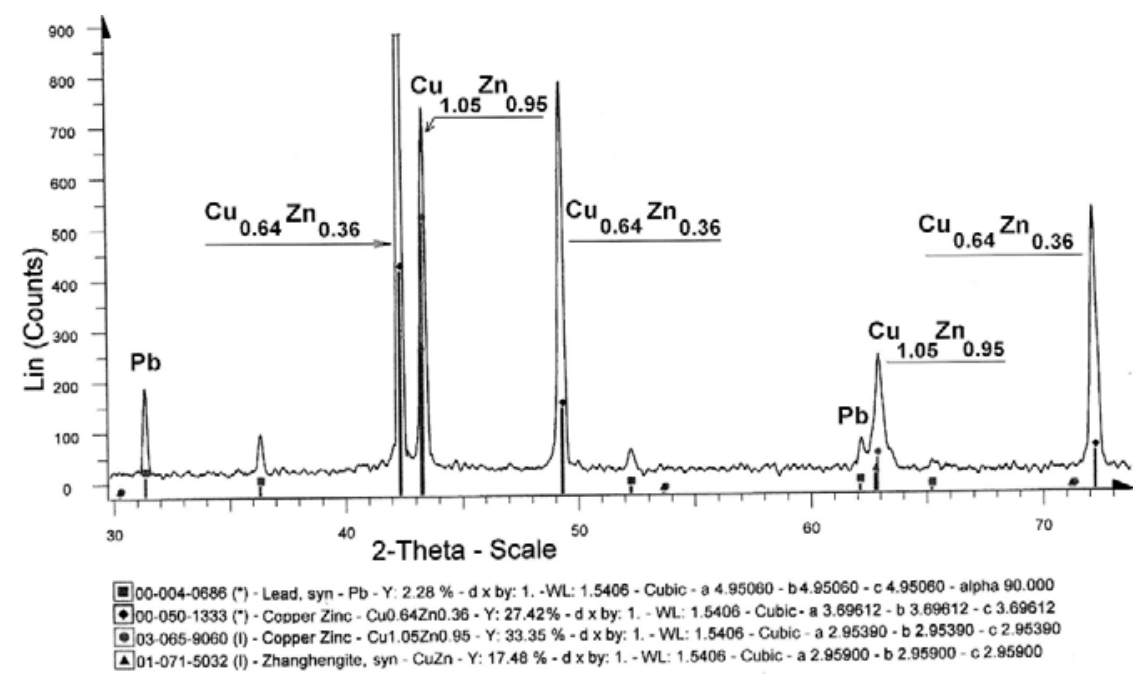

14.att. Cu-Zn sakausējuma pie tā legéejuma ar 9 elementiem fāžu sastāvu raksturojošā rentgenogramma. 
Kā redzams struktūras attēlā un kā apstiprina rentgenfāžu analīze (12.att.), sakausējumā, neskatoties uz leǵējošo elementu $\mathrm{Pb}, \mathrm{Fe}, \mathrm{Sn}$ klātbūtni, metalurğiskajā procesā papildus $\beta^{\prime}$ fāzei - intermetalīiam $\mathrm{CuZn}$ - ir izveidojies ļoti trauslais intermetalīds $\mathrm{Cu}_{5} \mathrm{Zn}_{8}$, t.i., $\gamma$ fãze.

Neskatoties uz to, ka sakausējums saturēja 1,9 mas.\% $\mathrm{Pb}$ un kopējais leǵējošo elementu daudzums bija 2,44 mas.\%, izstrādājums, kas izgatavots no šī sakausējuma, bez termiskās slogojuma, bet pie mehāniskā slogojuma, saplaisāja.

Lai spriestu par ķīmisko elementu ietekmi uz pašlaik ražošanā pielietoto jaunākās paaudzes $\mathrm{Cu}-\mathrm{Zn}$ sakausējuma struktūru un fāžu sastāvu, tika pētīts paraugs ar ķīmisko elementu sastāvu, kas parādīts 10. tabulā.

Kā parāda struktūru raksturojošie attēli (13.a,b att.), Cu-Zn sakausējumam ir izveidojusies netradicionāla misiņa struktūra, kurā ir redzami triju fāžu graudi. Ievērojami samazinātā daudzumā ir $\beta^{\prime}$, t.i., - CuZn intermetalīda fāze. Kā parāda rentgenfāžu analīze (14.att.), $\mathrm{Cu}-\mathrm{Zn}$ sakausējums šajā gadījumā sastāv no vara un cinka sakausējumu cietajiem šķīdumiem $\quad \mathrm{Cu}_{0,64} \mathrm{Zn}_{0,36}, \quad \mathrm{Cu}_{1,05} \mathrm{Zn}_{0,95} \quad$ un samazināta intermetalīda $\mathrm{CuZn} \beta^{\prime}$ făzes daudzuma.

Neskatoties uz leǵējošo elementu kopējo daudzumu, kas ir mazāks par literatūrā norādītajiem 7,0-8,0 mas.\%, šis sakausējums parādīja labu pretplaisāšanas izturību pie mehāniskā slogojuma.

Šo pētījumu novitāte, salīdzinot ar literatūras datiem, parāda būtiskas izmaiñas gan $\mathrm{Cu}-\mathrm{Zn}$ sakausējumu fāžu sastāvā, gan to struktūrā atkarībā no sakausējuma ķīmisko elementu sastāva.

Noteikta trauslā intermetalīda $\gamma$ fāzes $-\mathrm{Cu}_{5} \mathrm{Zn}_{8}$ veidošanās, kas papildus $\beta^{\prime}$ intermetalīdam nosaka $\mathrm{Cu}-\mathrm{Zn}$ sakausējumu trauslumu.

\section{SECINĀJUMI}

Ar optiskās mikroskopijas, ķīmisko elementu sastāva un rentgenfāžu analīzes metodēm, atkarībā no dzelzs sakausējumu legéejuma ar elementiem $\mathrm{Cr}$, Ni, Mo, Mn, Si un papildus leǵējuma ar V, W, Ti, Nb termiskā un mehāniskā slogojuma sakausējumos, ir noteiktas struktūru izmaiņas ar lokālu atšksirīgu polikristālisku bloku veidošanos, kas ir ar izmainītu fãžu sastāvu.

Atkarībā no dzelzs sakausējumu ķīmisko elementu sastāva, termiskā un mehāniskā slogojuma ierosinātās metālu rekristalizācijas, tajos veidojas gan trauslie karbīdu, gan intermetalītiskie savienojumi - $\mathrm{FeC}, \mathrm{Fe}_{3} \mathrm{C}, \mathrm{Fe}_{4} \mathrm{C}, \mathrm{Fe}_{2} \mathrm{~W}_{3} \mathrm{C}$, $\mathrm{Fe}_{4} \mathrm{~W}_{2} \mathrm{C}, \mathrm{Fe}_{3} \mathrm{Mo}_{3} \mathrm{C}$, kas savukārt metālu sakausējumam piedod trauslumu un ar savu veidošanos uz graudu robežvirsmām izraisa mikroplaisu veidošanos un ir izstrādājumu lūšanas cēlonis.

Pie zema $\mathrm{Cr}, \mathrm{Ni}, \mathrm{V}$ daudzuma bez citu leǵējošo elementu W, Co klātbūtnes un ilgstoša temperatūras un mehāniskā slogojuma, notiek metāla rekristalizācija ar savienojuma $\mathrm{Mn}_{4,6} \mathrm{Fe}_{0,4} \mathrm{Si}_{3}$ un karbīdu $\mathrm{Fe}_{3} \mathrm{C}, \quad \mathrm{Fe}_{4} \mathrm{C}$ veidošanos un sadalǐšanos, izdaloties $\mathrm{C}$ rentgenamorfa grafìta veidā.

Noteikts, ka $\mathrm{Cu}-\mathrm{Zn}$ sakausējumos pie nepietiekoša leǵējošo elementu daudzuma, bez trauslā intermetalīda $\mathrm{CuZn} \beta^{\prime}$ fāzes, veidojas trauslais intermetalīds $\mathrm{Cu}_{5} \mathrm{Zn}_{8}$.
Pie leǵējošo elementu - Pb, Fe, Sn, Al, Ni, Mn, Si, Cr summārā daudzuma 4,53 mas.\% Cu-Zn sakausējumā ir novērsta $\gamma$ fāzes $-\mathrm{Cu}_{5} \mathrm{Zn}_{8}$ veidošanās, ievērojami samazināts $\beta^{\prime}$ fāzes daudzums. Sakausējumu veido $\mathrm{Cu}_{0,64} \mathrm{Zn}_{0,36}$ un $\mathrm{Cu}_{1,05} \mathrm{Zn}_{0,95}$ cietie šks̄ìumi.

\section{LITERATŪRAS SARAKSTS}

[1] Faulkner, R.G., Williams, J.A., Sanchez, E.G., Marshall, A.W. (2003). Influence of $\mathrm{Co}, \mathrm{Cu}$ and $\mathrm{W}$ on microstructure of $9 \%$ steel weld metals. Material Science and Technology, 19 (3), 347-354. http://dx.doi.org/10.1179/026708303225009652

[2] Ueta Shigeki, Noda Toshiharu. Nickel alloy for heat resistant springs. Eur.Pat.Appl. EP1, 340, 825, Cl.C22 C19(03), 3 sep.2003, Ref.217675x.

[3] Neftema, Sh. Austenitic Ni-Cr-Fe alloy suitable for heat - resistant pipes in petroleum refining. Russ. RU 2, 149, 205 (Cl.C22 C30/00) 20 may 2000.

[4] Gorynin, I.V., Karzov, G.P., Zhuravlen, Yu.M., Galyatkin, S.N., Mikhaleva, E.J., Lebedeva, A.Yu., Yakovleva, G.P., Ermakova, E.N. Microalloyed Cr-Mo-V type steel wire for welding of pearlitic steel parts. Russ.RU 2, 194, 602. Abstract 138, 23, 2003. Ref.356624x.

[5] Crook, P., Caruso, M. Ni-Cr-Mo-Cu alloys resistant to acid attack. Brit.UK Pat. Appl.GB 2, 389, 590. Abstract 140, 3, 2004. Ref. 30217c.

[6] Hsieh Chih-Ching. Taiwan high - strength iron alloy. Ger. Gebrauchsmusterschrift DE 202, 007, 010, 241 (Cl.C22 C38/24), 3 Jan. 2008. Abstact 148, 5, 2008. Ref. 103740v.

[7] Wood, J.H., Feng, G.B., Cyril, G. Ni-Cr-Co alloys for cast and/ or welded parts of gas turbines. U.S. Pat. Appl. Publ. US 2004. 22, 661 (Cl.420-448, C22 C19105. Abstract 140, 9, 2004. Ref. 132050k

[8] Shchepochkina, Yu.A. Steel. Russ. RU 2, 313, 616 (Cl.C22 C38/54), 27 Dec 2007.

[9] Al-Mazrouee, A., Raman, R.K.Singh. (2007). High temperature oxidation of Cr-Mo steels in the context of Accelerated Rupture Testing for Creep Life Prediction. Journal of Pressure Vessel Technology. American Society of Mechanical Engineers, 129 (3), 454-459. http://dx.doi.org/10.1115/1.2748826

[10] Zhao Shuang-qun, Dang, Iian-xin, Xic, Xi-shan. (2003). Structure stability of Ni-Cr-Co base superalloy aged at $704^{\circ} \mathrm{C}$ and $760^{\circ} \mathrm{C}$. Zhongguo Youse Jinshu Xuebao, 13 (3), 565-569. Abstract Vol.140, 8, 2004, Ref.Nr. 140.115098.

[11] Lei Zhao, Hongyang Jing, Lianyong Xu, Yongdian Han, Junjie Xiu. (2012). Experimental study on creep damage evolution process of Type IV cracking in $9 \mathrm{Cr}-0,5 \mathrm{Mo}-1,8 \mathrm{~W}-\mathrm{VNb}$ steel welded joint. Engineering $\begin{array}{lll}\text { Failure } & \text { Analysis, } & 19,\end{array}$ http://dx.doi.org/10.1016/j.engfailanal.2011.09.003

[12] Abe, F. (2004). Coarsening behavior of lath and its effect on Creep rates in tempered martensitic 9Cr-W steels. Material Science and Engineering A 387-389, 565-569. http://dx.doi.org/10.1016/j.msea.2004.01.057

[13] Ladislav Falat, Milan Svoboda, Anna Vyrostkova, Ivan Petryshynets, Martin Sopko (2012). Microstructure and creep characteristics of dissimilar T91/TP316H martensitic/austenitic welded joint with Ni-based weld metal. Materials characterization 2012. MTL07191. http://dx.doi.org/10.1016/j.matchar.2012.06.014 www.elsevier.com/locate/matchar.

[14] Bhanu Sankara Rao, K., Sandhya, R., Mannan, S.L. (1993). Creepfatigue interaction behaviour of type 308 stainless steel weld metal and type 304 stainless steel. International Journal of Fatique, 15 (3), 221229. http://dx.doi.org/10.1016/0142-1123(93)90180-X

[15] Dehghan-Manshadi, A., Barnett, M.R., Hodgson, P.D. (2008). Recrystallization in AISI 304 austenitic stainless steel during and after hot deformation. Materials Science and Engineering A 485, 664-672. http://dx.doi.org/10.1016/j.msea.2007.08.026

[16] Akhari Mousavi, S.A.A., Farhadi Sartangi, P. (208). Effect of postweld heat treatment on the interface microstructure of explosively welded titanium-stainless steel composite. Materials Science and $\begin{array}{llll}\text { Engineering } & A & 494, & 329-336 .\end{array}$ http://dx.doi.org/10.1016/j.msea.2008.04.032

[17] Zheng Ming Sun, Hitoshi Hashimoto, Michel W. Barsoum. (2007). On the effect of environment on spontaneous growth of lead whiskers from commercial brasses at room temperature. Acta Materialia, 55, 3387-3396. http://dx.doi.org/10.1016/j.actamat.2007.01.035 
[18] Haruhiko Atsumi, Hisashi Imai, Shufeng Li, Katsuyoshi Kondoh Yoshiharu Kousaka, Akimichi Kojima. (2011). High strength, leadfree machinable $\alpha-\beta$ duplex phase brass $\mathrm{Cu}-40 \mathrm{Zn}-\mathrm{Cr}-\mathrm{Fe}-\mathrm{Sn}-\mathrm{Bi}$ alloys. Material Science and Engineering A 529, 275-281. http://dx.doi.org/10.1016/j.msea.2011.09.029

[19] Gialanella, S., Lutterotti, L. (2001). Metastable structures in $\alpha-\beta^{\prime}$ brass. Journal of Alloys and compounds 317-318, 479-484. http://dx.doi.org/10.1016/S0925-8388(00)01374-8

[20] Kondracki, M., Gauronski, J., Szajnar, J. (2005). Role of the intermetallic phases in technological process of fixture brasses. Journal of Materials Processing Technology 162-163, 332-335. http://dx.doi.org/10.1016/i.jmatprotec.2005.02.076

[21] McEvily, A.J. (2002). Metal Failures: mechanisms, analysis, prevention. NewYork: John Wiley and Sons.Inc.

[22] Gale, W.F., Totemeier, T.C. (2004). Smithells Metals Reference Book. Elsevier.

[23] Schumann, H. (1991). Metallographie. Wiley-VCH Verlag GmbH

[24] Standarts GOST 1763-68 Сталь. Методы определения глубины обезуглероженного слоя.

Ingrida Vitina, Dr.habil.chem. degree awarded by the Institute of Inorganic Chemistry of the Latvian Academy of Sciences in the year 1994. Experience: Head of Laboratory of Metal Electrodeposition of the Institute of Inorganic Chemistry of the Riga Technical University (RTU) in the years 1987-2012.
International scientific collaboration: The Institute of Chemical Kinetics and Combustion of the Russian Academy of Sciences, for the research project on the electrodeposition of suprconductive layers in the years 1974-1991. The Laboratory of Metal Electrodeposition of the Institute of Inorganic Chemistry of RTU was included since the year 1998 in the international catalogue "Survey of Corrosion Research Laboratories" issued by the International Corrosion Council (ICC), and Ingrīda Vītina was elected as a member of ICC in the year 2008: http://www.icc-net.org/ICCmembers_Latvia.html E-mail: ingrida.vitina@inbox.lv

Aija Krumina, diplomaed chemist. Education: Faculty of Chemistry of the University of Latvia. Speciality: Analytical chemistry, X-ray diffraction analysis. Co-author of 23 publications. Experience: Research Assistant at the Institute of Inorganic Chemistry of RTU in the years 1995-2013. E-mail: kruminaaija2@gmail.com

Velta Belmane, Master of Science degree was conferred by the Academic Information Centre, decision No. 142/20367 on 2 October 2013, according to the Cabinet of Ministers Regulations No.142 (Article 5, 2 March 2012), on the ground of referencing the diploma of the Faculty of Physics and Mathematics of the University of Latvia. Speciality: Optical and scanning electron microscopy. Co-author of 37 publications. Experience: Research Assistant at the Institute of Inorganic Chemistry of RTU in the years 1991-2013. E-mail: velta.belmane@gmail.com

\section{Ingrida Vitina, Aija Krumina, Velta Belmane. Formation of Intermetallic Compounds and Changes in Metal Alloy Structures Caused by Different Elemental Compositions of the Metal Alloys}

Elemental composition of different steel alloys may vary from traditional 5 elements $\mathrm{Cr}, \mathrm{Ni}, \mathrm{Mo}, \mathrm{Mn}, \mathrm{Si}$ (apart from Fe, C, P, S) with different wt. \% to even 10 or more, when the steel alloy contains also V, W, Ti, Nb, Al, Co, Ta, Zr, Re. There is a similar variety of copper alloys, where presence of $\mathrm{Pb}, \mathrm{Ni}, \mathrm{Fe}, \mathrm{Co}, \mathrm{Ti}, \mathrm{Zr}, \mathrm{Cr}$ and other elements apart from conventional alloy elements $\mathrm{Cu}, \mathrm{Zn}, \mathrm{Sn}$ is significant in whole with the aim to ensure them high mechanical, heat and corrosion resistance. As a result of our studies, using optical microscopy, metal elemental and $\mathrm{X}$-ray diffraction analysis, it was found that a number of intermetallic compounds, e.g. $\mathrm{FeC}, \mathrm{Fe}_{3} \mathrm{C}, \mathrm{Fe}_{2} \mathrm{~W}_{3} \mathrm{C}, \mathrm{Fe}_{4} \mathrm{~W}_{2} \mathrm{C}$, form under exploitation conditions, in the case of inadequate elemental composition, initial non-uniform alloy structure and under mechanical and thermal loads. The intermetallic compounds embrittle the metal alloy and are the reason of breaking of steel articles. In another case, insufficient alloying of the steel with $\mathrm{Cr}, \mathrm{Ni}, \mathrm{V}$ and exploitation mechanical and thermal loads have caused a complete metal recrystallization with formation of $\mathrm{Mn}_{4.6} \mathrm{Fe}_{0.4} \mathrm{Si}_{3}$ compound, decomposition of $\mathrm{Fe}_{3} \mathrm{C}$ and $\mathrm{Fe}_{4} \mathrm{C}$ and carbon release as $\mathrm{X}$-ray amorphous graphite. Similarly in copper alloys with a reduced content of alloying metals, brittle intermetallic $\mathrm{CuZn}$ and $\mathrm{Cu}_{5} \mathrm{Zn}_{8}$ compounds form already in the metallurgical process, causing breaking of the articles. Both hot-dip and electrodeposited metal coatings are embrittled on their obtaining by formation of intermetallic compounds. In hot-dip galvanizing, formation of vertical and horizontal cracks in the zinc coating and scaling of the zinc coating off a substratum are caused by a very brittle $\mathrm{Fe}_{3} \mathrm{Zn}_{10}$, which forms apart from a usually formed intermetallic $\mathrm{FeZn} \mathrm{n}_{13}$. Formation of cracks in $\mathrm{Sn}-\mathrm{Co}$ alloy layers may be caused by formation of $\mathrm{CoSn}_{2}$ compound in a thick layer.

At the total amount of 4.53 wt.\% of the alloying elements $\mathrm{Pb}, \mathrm{Fe}, \mathrm{Sn}, \mathrm{Al}, \mathrm{Ni}, \mathrm{Mn}, \mathrm{Si}, \mathrm{Cr}$, formation of $\gamma$ phase $\mathrm{Cu}_{5} \mathrm{Zn}_{8}$ is prevented, the amount of $\beta^{\prime}$ phase is reduced, the alloy is formed by the solid solutions $\mathrm{Cu}_{0,64} \mathrm{Zn}_{0,36}$ and $\mathrm{Cu}_{1,05} \mathrm{Zn}_{0,95}$.

\section{Ингрида Витиня, Айя Круминя, Велта Белмане. Образование интерметаллических - химических соединений в сплавах и их} влияние на изменение структуры в зависимости от химического состава

Число и содержание элементов (в вес.\%) в железных сплавах может меняться в пределах от 5 основных элементов - Cr, $\mathrm{Ni}, \mathrm{Mo}, \mathrm{Mn}$, $\mathrm{Si}$ (кроме Fe, C, P, S) до 10, когда сплавы дополнительно содержат V, W, Ti, Nb, Al, Co, Ta, Zr, Re.

В медных сплавах различного элементного состава, кроме основных элементов - $\mathrm{Cu}, \mathrm{Zn}$, Sn, существенное влияние на увеличение механических свойств и стойкости против химической и высокотемпературной коррозии таже имеют элементы $\mathrm{Pb}, \mathrm{Ni}, \mathrm{Co}, \mathrm{Fe}, \mathrm{Cr}$, $\mathrm{Zn}, \mathrm{Ti}$.

Применением оптической и металлографической микроскопии, определением рентгенофазового и элементного состава сплавов установлено, что в случае высокого термического и механического воздействия на железные сплавы, при несоответствии эксплуатационным требованиям как по химическому элементному составу, так и в результате неоднородности структуры, образуются интерметаллические соединения $\mathrm{FeC}, \mathrm{Fe}_{3} \mathrm{C}, \mathrm{Fe}_{2} \mathrm{~W}_{3} \mathrm{C}, \mathrm{Fe}_{4} \mathrm{~W}_{2} \mathrm{C}, \mathrm{Fe}_{3} \mathrm{Mo}_{3} \mathrm{C}$, что придает сплавам хрупкость. Недостаточное легирование железных сплавов $\mathrm{Cr}, \mathrm{Ni}, \mathrm{V}$ при их механической и термической нагрузке является причиной образования соединения $\mathrm{Mn}_{4.6} \mathrm{Fe}_{0.4} \mathrm{Si}_{3}$ и разложения карбидов $\mathrm{Fe}_{3} \mathrm{C}$ и $\mathrm{Fe}_{4} \mathrm{C}$ с выделением С в виде рентгеноаморфного графита.

В медных сплавах, в зависимости от элементного состава и при отсутствии легирующих элементов $\mathrm{Ni}, \mathrm{Fe}, \mathrm{Pb}$, могут образоваться хрупкие интерметаллические соединения $\mathrm{CuZn}$ и $\mathrm{Cu}_{5} \mathrm{Zn}_{8}$.

При взаимодействии расплавленного цинка с железом образование хрупкого интерметаллида $\mathrm{Fe}_{3} \mathrm{Zn}_{10}$, наряду с соединением, определяющим адгезию, $\mathrm{FeZn}_{13}$, вызывает горизонтальное и вертикальное растрескивание цинкового покрытия.

Растрескивание покрытия из сплава Sn-Co как при электроосаждении, так при термическом воздействии вызывает образование интерметаллида $\mathrm{CoSn}_{2}$. 